University of Chicago Law School

Chicago Unbound

Public Law and Legal Theory Working Papers

Working Papers

2009

\title{
A Few Words in Favor of Cultivating an Incest Taboo in the Workplace
}

Mary Anne Case

Follow this and additional works at: https://chicagounbound.uchicago.edu/public_law_and_legal_theory

Part of the Law Commons

Chicago Unbound includes both works in progress and final versions of articles. Please be aware that a more recent version of this article may be available on Chicago Unbound, SSRN or elsewhere.

\section{Recommended Citation}

Mary Anne Case, "A Few Words in Favor of Cultivating an Incest Taboo in the Workplace" (University of Chicago Public Law \& Legal Theory Working Paper No. 263, 2009).

This Working Paper is brought to you for free and open access by the Working Papers at Chicago Unbound. It has been accepted for inclusion in Public Law and Legal Theory Working Papers by an authorized administrator of Chicago Unbound. For more information, please contact unbound@law.uchicago.edu. 


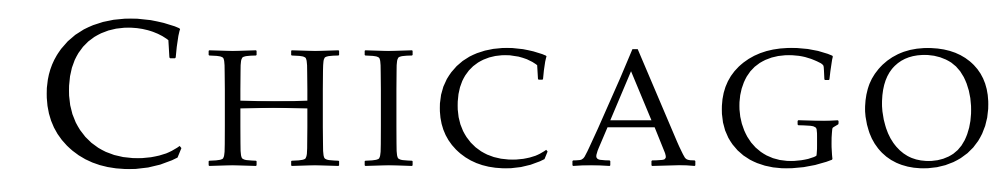

Public Law ANd Legal Theory Working PAPer No. 263

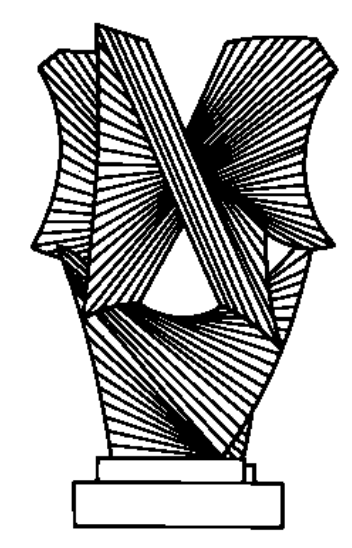

\section{A FEW WORDS IN FAVOR OF CULTIVATING AN INCEST TABOO IN THE WORKPLACE}

Mary Anne Case

\section{THE LAW SCHOOL THE UNIVERSITY OF CHICAGO}

April 2009

This paper can be downloaded without charge at the Public Law and Legal Theory Working Paper Series: http://www.law.uchicago.edu/academics/publiclaw/index.html and The Social Science Research Network Electronic Paper Collection. 


\title{
A FEW WORDS IN FAVOR OF CULTIVATING AN INCEST TABOO IN THE WORKPLACE
}

\author{
Mary Anne Case ${ }^{* \dagger}$
}

More than thirty years ago, in the April 1978 issue of Redbook magazine, anthropologist Margaret Mead, after acknowledging the contributions the passage and subsequent elaboration and enforcement of the Equal Pay Act and Title VII had made to the progress of women in the workplace, insisted that "new laws will not be sufficient to protect women-and men too, for that matter-from the problems of sexual harassment on the job .... [W] [Weed new taboos."1 Specifically, according to Mead, "like the family, the modern business and the modern profession must develop incest taboos."

In this abbreviated essay, I want to endorse large parts of Mead's proposal and to explain how it fits into my broader project of a unified field theory of the treatment of liking and not liking in the law of employment discrimination, a theory accounting for both sexual and nonsexual forms of attraction between decision-makers in the workplace and those they have the power to hire, fire, or promote.

Several features I see in the analogy to familial incest taboos are relevant to my endorsement of Mead's A Proposal: We Need Taboos on Sex at Work. First, such taboos, while often embodied in law, do not rely principally on legal enforcement but on internalized social norms for their power. The reason that most parents do not initiate sexual relations with or even lust after their children is by and large not because they would go to jail if they were to do so. Moreover, a few may find the very existence of a

* Arnold I. Shure Professor of Law, University of Chicago Law School.

$\dagger$ A version of this essay appears in FEMINIST AND QUEER LEgAL THEORY: INTIMATE ENCOUNTERS, UnCOMFORTABle CONVERSATIONS (Martha Albertson Fineman, Jack E. Jackson \& Adam P. Romero eds., forthcoming 2009). Previous versions of this paper were presented at Cornell Law School's 2002 Uncomfortable Conversation on Sexuality and Feminist Theory, Emory University's 2005 Uncomfortable Conversation on Feminist and Queer Legal Theory: Convergences and Departures, under the auspices of the Feminism and Legal Theory Project; and at the University of Chicago Law School's 2008 conference entitled, Emotion in Context: Exploring the Interaction between Emotions and Legal Institutions . I am grateful to the participants in these events, particularly to organizers Susan Bandes, Martha Fineman, Jack Jackson, and Adam Romero; as well as to Jane Cohen, Adrienne Davis, Liz Emens, Carolyn Frantz, Andrew Greeley, Janet Halley, John Hayes, Claire Hill, Irina Manta, Teemu Ruskola, Vicki Schultz, Helen Witt, Noah Zatz, and Viviana Zelizer for comments; and to Jake Glazeski, Deborah Megdal, and Margaret Schilt for research assistance.

1. Margaret Mead, A Proposal: We Need Taboos on Sex at Work, RedBooK, Apr. 1978, reprinted in SEXUALITY AND ORGANIZATIONS: ROMANTIC AND COERCIVE BEHAVIORS AT WORK 53, 54 (Dail Ann Neugarten \& Jay M. Shafritz eds., 1980).

2. Id. at 54 . 
taboo stimulates the forbidden desire, and some may think about it and feel revulsion at the thought, but I suspect that, for most parents, their children simply are not thought of as in the category of potential sex partners. In this sense, the thought of sex with one's children may be less like the thought of consuming cockroaches (disgusting) or marijuana roaches (potentially attractive, but forbidden) and more like the thought of consuming hemp fiber-a thought that does not frequently occur because hemp fiber is not generally thought of as comestible.

Second, no incest taboo that I know of categorically prohibits sex between family members. (In most of the U.S., for example, first cousins are permitted to marry; in some parts of the world, first cousins are preferred as spouses.) But at the core of most incest taboos, whatever else they may also prohibit, is usually a prohibition on ancestor-descendent sex. Similarly, what I would want to focus on discouraging in the workplace is not any and all eroticism or search for sexual partners, but sex initiated between people hierarchically arranged in a direct reporting relationship with one another.

A third feature of how both Mead and I understand an incest taboo that is relevant here is that we see one potentially valuable function of incest taboos to be the creation of a safe space, free from sexual demand, threat or possibility. The space is not the geographical space of the home or the workplace, it is the metaphysical space of a relationship, such as that between parent and child or supervisor and supervisee.

I first endorsed the notion that it would be useful to think of sex in the workplace in terms of an incest taboo in 1994, in a comment made at a conference on the Centrality of Sexuality to Feminist Legal Theory, sponsored by Martha Fineman's Feminism and Legal Theory Project. The overwhelming majority of participants at that conference fell into one of two groups: those who thought that sexuality was quite central to feminist legal theory and this was a good thing and those who worried that sexuality was not yet as central as they thought it should be. I was in a tiny minority of participants who expressed the view that sexuality was perhaps a bit too central. Perhaps for this reason, my suggestion of an incest taboo in the workplace was not at all well received. Some objectors took the view that eroticism is central to our personalities; we spend so much time at work that we have few places other than the workplace to express it; if we aren't allowed to be freely erotic in the workplace we are basically condemned to a life of celibacy and erotic repression. Others went on to say that eroticism was a vital part of their particular work as teachers, that the teacher-student relationship was necessarily and productively erotic, and that any interference with its eroticism would be detrimental. I had responses to 
these objections, but the vehemence of the objections delayed me for years in pursuing the project.

Those intervening years brought scandals from Clinton-Lewinsky (in which consensual sexual relations with an intern led to the impeachment of the President) to the Aberdeen Proving Grounds (in which a dozen male Army officers were prosecuted for sexual assault on female trainees under their command), which strengthened my conviction that Mead's suggestion was a good one. But they also brought a series of cogently and passionately argued defenses of sexual relationships between coworkers by a number of distinguished academics from a variety of perspectives, including Janet Halley's (portions of which were published as Sexuality Harassment) ${ }^{3}$ and Vicki Schultz's (most fully elaborated in The Sanitized Workplace), ${ }^{4}$ each of which must be dealt with if Mead's proposal is to gain any traction.

Incest taboos at work have frequently been urged by others in the interests of the good functioning of a given workplace, but my own focus is more narrowly on discouraging those relationships that pose a risk of limiting equality of opportunity in the workplace on grounds of sex. It is also not my goal here to object to unequal power dynamics or hierarchical imbalance in sexual relationships generally. While I must confess that I personally tend to be attracted to my equals, not my hierarchical superiors or my subordinates, my argument for an incest taboo in the workplace would leave room for sexual attraction and relationships between a high ranking, powerful individual and those of lower rank, so long as the higher ranking individual avoids initiating relationships with those lower down on the same totem pole.

My focus in this discussion will not be on the relationship between the perpetrator and either the direct victim of sexual harassment or the direct beneficiary of a quid pro quo deal, rather it will be on the problems created for other employees and for equal employment opportunity when a boss engages in sexual relationships, whether or not welcome or fully consensual, with subordinates in a workplace. In an as yet unpublished portion of her work, Sexuality Harassment, ${ }^{5}$ Janet Halley calls this "thirdparty harassment” and is critical of policies, such as the Equal Employment Opportunity Commision's (EEOC) Guidance on Employer Liability under

3. Janet Halley, Sexuality Harassment, in Directions In SEXUAl Harassment LaW 183, 189, 197-98 (Catharine A. MacKinnon \& Reva B. Siegel eds., 2004).

4. Vicki Schultz, The Sanitized Workplace, 112 YALE L.J. 2061, 2164-67 (2003).

5. Draft on file with the author. supra note 3 and,Halley, Queer Theory by Men in FEMINIST AND QueER Legal TheORY: INTIMATE ENCOUNTERS, UnCOMFORTABle CONVERSATIONS (Martha Albertson Fineman, Jack E. Jackson, \& Adam P. Romero eds., forthcoming 2009). 
Title VII for Sexual Favoritism, ${ }^{6}$ that would provide a remedy to a person denied a job benefit that went to someone else in part because that person is involved in sexual relations with a decision-maker in the workplace. One of Halley's concerns, which I share, is that queer relationships between a boss and a subordinate will be particularly vulnerable to hostile environment harassment complaints by other employees.

But, in contrast to Halley, I think there is much to be said in favor of Title VII liability for some sexual favoritism. Let me use the example of a workplace like the Clinton White House at the time of the Lewinsky affair to illustrate why. It is clear all around that Monica Lewinsky herself had no viable Title VII claim: She sought out and welcomed a relationship with her boss and on balance seems to have suffered more employment benefit than detriment. Although she felt herself banished from the White House, she did step up from her unpaid internship to a paid job at the Pentagon, and then received Vernon Jordan's help finding a private sector job because of her relationship with the President. ${ }^{7}$ But Clinton's interest in Monica Lewinsky was far from unique.

With a boss like Clinton in charge of personnel decisions, women he finds attractive could have special opportunities for advancement. In the Clinton White House itself, however, Deputy Chief of Staff Evelyn Lieberman apparently took it upon herself to shunt attractive women away from Clinton, lest he hit on them. ${ }^{8}$ Under circumstances such as these, the equal employment opportunities of both attractive and unattractive women and men can be compromised on account of their sex, so it is hard to see who the unaffected third parties are.

It may be worth noting that the EEOC's Sexual Favoritism guidelines were first issued under the chairmanship of Clarence Thomas, someone who may have known a thing or two about the effect of a supervisor's manifesting sexual interest in a subordinate on employment opportunity in a workplace. .There are a few aspects of the Title VII's treatment of sexual favoritism on which it seems Clarence Thomas, the EEOC, Halley, the case law, and I all agree, notably "that Title VII does not prohibit isolated instances of preferential treatment based upon consensual romantic relationships. An isolated instance of favoritism toward a 'paramour' (or a spouse, or a friend) may be unfair, but it does not discriminate against

6. Equal EMPloyment OpPoRTUnity COMmission, Policy Guidance on EMPLOYER Liability UNDER TITLE VII FOR SEXUAL FAVORITISM, EEOC Notice No.915.048 (Jan. 12, 1990), available at http://eeoc.gov/policy/docs/sexualfavor.html [hereinafter EEOC].

7. See, e.g., ANDREW MORTON, MONICA's STORY 97, 168-71 (1999).

8. Id. at 93-95. 
women or men in violation of Title VII, since both are disadvantaged for reasons other than their genders." While hiring an individual paramour may violate nepotism rules, and may be undesirable from the perspective of the good functioning of a particular workplace, it is not sex discrimination because no one of any sex, other than this particular person, could have gotten the job. Similarly, hiring those you are close to in a nonsexual way may in a given workplace be undesirable and may violate nepotism rules, but it is not necessarily discrimination on a forbidden ground.

If, however, you only hire your friends and you can only make friends with other white Anglo-Saxon Protestant males, your hiring decisions could well be found to violate Title VII. In the same way, if you only hire people you are sexually attracted to and you are only sexually attracted to men or women, or some subset of men or women, and they are the people who are advantaged in your workplace, then you are making use of a forbidden ground in your employment decisions. This led the EEOC—correctly in my view - to determine that "widespread favoritism may constitute hostile environment harassment" such that "both male and female colleagues who do not welcome this conduct can establish a hostile work environment in violation of Title VII regardless of whether any objectionable conduct is directed at them and regardless of whether those who were granted favorable treatment willingly bestowed the sexual favors."10

Vicki Schultz insists:

[I]t is important to recognize that the problem of favoritism is not confined to dating and sexual relationships. After all, supervisors may also develop intimate attachments of a nonsexual nature that predispose them to favor particular employees over others. As women have long complained, playing golf regularly with the (heterosexual male) boss can lead to sex-based patterns of favoritism for men who do so .... [T] he problems of favoritism and/or coercion cannot be solved by discouraging dating and sexual intimacy alone. ${ }^{11}$

I quite agree with this analysis, and with Schultz's conclusion that "organizations that discourage romantic relationships would also have to consider the potential for discriminatory dynamics to develop in connection with nonsexual forms of affiliation that can affect a worker's employment

9. EEOC, supra note 6, at 2 .

10. Id.

11. Vicki Schultz, The Sanitized Workplace, in Feminist AND QueER Legal TheORY: InTIMATE ENCOUNTERS, UnCOMFortable CONVERSATIONS (Martha Albertson Fineman, Jack E. Jackson \& Adam P. Romero eds., forthcoming 2009). 
prospects. $^{\text {12 }}$

If organizations were indeed prompted to treat sexual and nonsexual affiliation between supervisors and subordinates in pari materia, Schultz seems to hope the result would be fewer categorical prohibitions on sexual relationships between coworkers. My hopes tend in a somewhat different direction, toward encouraging greater scrutiny of the forbidden grounds that may lurk beneath a boss's preferring those he is comfortable with or attracted to, whether sexually or not. In the landmark case of Price Waterhouse v. Hopkins, the United States Supreme Court was able to see that, "if an employee's flawed 'interpersonal skills' can be corrected by a soft-hued suit or a new shade of lipstick, perhaps it is the employee's sex and not her interpersonal skills that has drawn the criticism."13 But, more recently, courts such as the Second Circuit in Fisher v. Vassar College seem more willing to accept at face value, as a justifiable basis for an adverse employment decision, the fact that decision-makers in the workplace "simply did not like [the plaintiff] and did not wish to establish a career-long professional association with her," ${ }^{, 14}$ without as careful attention to the extent to which forbidden grounds were a factor in the decisionmakers' dislike.

My objective is not to ban all warm feelings from the workplace. But I have noticed that, even where a supervisor links sexual interest in subordinates with a genuine mentoring opportunity that can survive a refusal of-or an eventual end to- the sex,, too often the supervisor who offers special mentorship to "the boys" he pals around with and "the girls" he sleeps with leaves out those women who are never offered an opportunity to be either one of the boys or the object of his sexual interest. Those who divide their circle into "bros" and "hos", even if they don't put bros before hos, tend to leave out the women who are neither. (If all men can be brothers, are all women whores?)

I note with interest that, from time immemorial, some workplaces did indeed have prohibitions on a supervisor having too close a relationshipwhether or not sexual-with a subordinate, although equal employment opportunity was not the announced purpose of most such prohibitions. Beyond a garden-variety employer's anti-nepotism and anti-cronyism policies, what attracts my interest are rules designed for two special kinds of workplace-the Catholic Church's ban on particular friendships and the

12. Id.

13. Price Waterhouse v. Hopkins, 490 U.S. 228, 256 (1989).

14. Fisher v. Vassar College, 70 F.3d 1420, 1436 (2d Cir. 1995). 
military's anti-fraternization policies. The notion behind the ban on particular friendships is that, in an extremely close working environment such as a monastery, relations between coworkers -and especially between a superior and each of his subordinates in the community, should, for want of a better word, be equidistant. If the abbot and one of the other monks were really close, whether sexually or not, the Church feared an adverse effect on the dynamic of the whole community. In more recent times, criticism of particular friendships has come into bad odor because it is associated with a Catholic repudiation of sex and potential obsession with homosexual sodomy. It is important to note, however, that the traditional ban was not simply on sexual or romantic relationships, but extended equally to sexual and nonsexual forms of friendship.

Similarly, military bans on fraternization in the ranks, designed to promote good order and discipline and to avoid the appearance of partiality, have always extended far beyond sexual and romantic relationships to other forms of close friendships and business dealings. ${ }^{15}$ Although "fraternization" is too often used today as a mere synonym for prohibited sexual interactions, the military prohibited officers from fraternizing with enlisted personnel long before there were women in the armed forces or widespread expressions of concern about homosexuality in the military. Military anti-fraternization rules were concerned, not only with officers having sex with subordinates, but about them gambling or carousing or going into business with them as well.

Schultz worries that taboos on workplace sex lead male supervisors to be unwilling to go behind closed doors or on business trips with (attractive) female coworkers. ${ }^{16}$ Like Mead, I would argue, by contrast, that it is precisely in the absence of an effective taboo that we worry about leaving men unsupervised with women or adults unsupervised with children.

Is there a solution to this problem that is not as sex-negative as mine or Mead's, that doesn't repress eroticism or embrace even temporary celibacy? Perhaps because I define myself as a sameness feminist, opposed in principle to categorical sex distinctions in the way men and women are treated, I find myself drawn back to Richard Wasserstrom's early essay analogizing race and sex discrimination, in which he provocatively suggests that perhaps there will always be sex discrimination and therefore inequality

15. See, 10 U.S.C. § 934 (2000) (article of the Uniform Code of Military Justice under which fraternization is prosecuted); accord MANUAL FOR COURTS-MARTial, United STATES pt. IV, qף 60a, 83c, \& App. 23-21 (2008) (enumerating "Fraternization" as a punishable military offense and explaining that "the offense of fraternization is based on longstanding custom . . . [as] prejudicial to good order and discipline").

16. Schultz, supra note 11. 
of opportunity on grounds of sex until we are all perfectly bisexual. ${ }^{17}$ This paradoxically makes the bisexual harasser, who was the bogeyman of early sexual harassment cases, as much a solution as a problem. In a world of perfect bisexuality, where both friendship and sexual interest were on offer, if not to everyone indiscriminately then at least not on the basis of the forbidden ground of one's sex, even widespread favoritism, sexual or not, might not raise Title VII sex discrimination concerns, and my own reasons for cultivating an incest taboo in the workplace might vanish, although not those reasons typically addressed by anti-fraternization or anti-nepotism rules. I realize, however, that it will be hard enough to develop an incest taboo in the workplace. To develop perfect bisexuality among all the people who might enter into is not necessarily undesirable, but is an even less attainable goal.

Readers with comments may address them to:

Professor Mary Anne Case

University of Chicago Law School

1111 East 60th Street

Chicago, IL 60637

macase@uclaw.uchicago.edu

17. Richard A. Wasserstrom, Racism, Sexism, and Preferential Treatment: An Approach to the Topics, 24 UCLA L. REV. 581, 606 (1977). 


\section{The University of Chicago Law School Public Law and Legal Theory Working Paper Series}

For a listing of papers 1-99 please go to http://www.law.uchicago.edu/academics/publiclaw/1-199.html

200. Susan Bandes, The Heart Has Its Reasons: Examining the Strange Persistence of the American Death Penalty (January 2008)

201. Susan Bandes, After Innocence: Framing Wrongful Convictions (January 2008)

202. Ariel Porat, Expanding Restitution: Liability for Unrequested Benefits (January 2008)

203. Adam B. Cox, Deference, Delegation and Immigration Law (February 2008)

204. Ariel Porat and Alon Harel, Aggregating Probabilities across Offences in Criminal Law (March 2008)

205. Jonathan S. Masur, Process as Purpose: Administrative Procedures, Costly Screens, and Examination at the Patent Office (March 2008, revised July 2008)

206. Eric A. Posner and Cass R. Sunstein, Should Green house Gas Permits Be Allocated on a Per Capita Basis? (March 2008)

207. Eric A. Posner, Human Welfare, Not Human Rights (March 2008)

208. Susan Bandes, Victims, “Closure,” and the Sociology of Emotion (March 2008)

209. Cass R. Sunstein, Is OSHA Unconstitutional? (March 2008)

210. Shyamkrishna Balganesh, Foreseeability and Copyright Incentives

211. Lee Fennell, Slices and Lumps (March 2008)

212. M. Todd Henderson, Citing Fiction (March 2008)

213. Jacob E. Gersen and Eric A. Posner, Soft Law (March 2008)

214. Christopher R. Berry and Jacob E. Gersen, The Unbundled Executive (March 2008)

215. Cass R. Sunstein and Reid Hastie, Four Failures of Deliberating Groups (April 2008)

216. Adam M. Samaha, Judicial Transparency in an Age of Prediction (April 2008)

217. Stephen J. Choi, Mitu Gulati, \& Eric A. Posner, Which States Have the Best (and Worst) High Courts? (May 2008)

218. Cass R. Sunstein, Two Conceptions of Irreversible Environmental Harm (May 2008)

219. Jonathan R. Nash, The Uneasy Case for Transjurisdictional Adjudication (June 2008)

220. Adam B. Cox and Thomas J. Miles, Documenting Discrimination? (June 2008)

221. Susan Bandes, Emotions, Values and the Construction of Risk (June 2008)

222. Jonathan R. Nash, Taxes and the Success of Non-Tax Market-Based Environmental Regulatory Regimes (July 2008)

223. Thomas J. Miles and Cass R. Sunstein, Depoliticizing Administrative Law (June 2008)

224. Eric A Posner, Erga Omnes Norms, Institutionalization, and Constitutionalism in International Law (July 2008)

225. Thomas J. Miles and Eric A. Posner, Which States Enter into Treaties, and Why? (July 2008)

226. Cass R. Sunstein, Trimming (August 2008)

227. Jonathan R. Nash, The Majority That Wasn't: Stare Decisis, Majority Rule, and the Mischief of Quorum Requirements (August 2008)

228. Eric A. Posner, Boumediene and the Uncertain March of Judicial Cosmopolitanism (August 2008)

229. Cass R. Sunstein, Second Amendment Minimalism: Heller as Griswold (August 2008)

230. John Bronsteen, Christopher Buccafusco, and Jonathan Masur, Happiness and Punishment (September 2008)

231. Adam B. Cox and Thomas J. Miles, Judicial Ideology and the Transformation of Voting Rights Jurisprudence (September 2008)

232. Daniel Abebe and Jonathan S. Masur, A Nation Divided: Eastern China, Western China and the Problem of Global Warming (September 2008)

233. Irina D. Manta, Privatizing Trademarks (abstract only) (September 2008) 
234. Paul J. Heald, Testing the Over- and Under-Exploitation Hypothesis: Bestselling Musical Compositions (1913-32) and Their Use in Cinema (1968-2007) (September 2008)

235. Brian Leiter, Nietzsche’s Naturalism Reconsidered (September 2008)

236. Paul Heald, Optimal Remedies for Patent Infringement: A Transactional Model (September 2008)

237. Cass R. Sunstein, Beyond Judicial Minimalism (September 2008)

238. Bernard E. Harcourt, Neoliberal Penality: The Birth of Natural Order, the Illusion of Free Markets (September 2008)

239. Bernard E. Harcourt, Abolition in the U.S.A. by 2050: On Political Capital and Ordinary Acts of Resistance (September 2008)

240. Bernard E. Harcourt, Supposons que la discipline et la sécurité n'esistent pas Rereading Foucault's Collége de France Lectures (with Paul Veyne) (September 2008)

241. Richard H. McAdams, Beyond the Prisoner's Dilemma: Coordination, Game Theory and the Law (October 2008)

242. Dhammika Dharamapala, Nuno Garoupa, and Richard H. McAdams, Belief in a Just World, Blaming the Victim, and Hate Crime Statutes (October 2008)

243. Richard H. McAdams, The Political Economy of Criminal Law and Procedure: The Pessimists' View (October 2008)

244. Richard H. McAdams and Thomas S. Ulen, Behavioral Criminal Law and Economics (November 2008)

245. Cass R. Sunstein, Judging National Security Post-9/11: An Empirical Investigation (November 2008)

246. Brian Leiter, Naturalizing Jurisprudence: Three Approaches (November 2008)

247. Adam M. Samaha, Originalism’s Expiration Date (November 2008)

248. Eric A. Posner and Adrian Vermeule, Crisis Governance in the Administrative State: 9/11 and the Financial Meltdown of 2008 (November 2008)

249. Lee Anne Fennell, Adjusting Alienability (November 2008)

250. Nuno Garoupa and Tom Ginsburg, Guarding the Guardians: Judicial Councils and Judicial Independence (November 2008)

251. Tom Ginsburg, The Clash of Commitments at the International Criminal Court (November 2008)

252. Tom Ginsburg, Constitutional Afterlife: The Continuing Impact of Thailand's Post-Political Constitution (November 2008)

253. Cass R. Sunstein and Richard Zechkauser, Overreaction to Fearsome Risks (December 2008)

254. Gilbert Metcalf and David Weisbach, The Design of a Carbon Tax (January 2009)

255. David Weisbach, Responsibility for Climate Change, by the Numbers (January 2009)

256. Daniel Abebe, Great Power Politics and the Structure of Foreign Relations Law (January 2009)

257. Brian Leiter, Moral Skepticizm and Moral Disagreement in Nietzsche (January 2009)

258. Adam B. Cox, Immigration Law’s Organizing Principles, (February 2009)

259. Adam Samaha, Gun Control after Heller: Threats and Sideshows from a Social Welfare Perspective (February 2009)

260. Lior Strahilevitz, The Right to Abandon (February 2009)

261. Lee Fennell, Commons, Anticommons, Semicommons (February 2009)

262. Adam B. Cox and Cristina M. Rodríguez, The President and Immigration Law (March 2009)

263. Mary Anne Case, A Few Words in Favor of Cultivating an Incest Taboo in the Workplace (April 2009) 